\title{
Impact of $P$ fertilisation on the growth performance of black locust (Robinia pseudoacacia L.) in a lignite post-mining area in Germany
}

\author{
M. Kanzler, C. Böhm, D. Freese
}

Kanzler M., Böhm C., Freese D., 2015. Impact of P fertilisation on the growth performance of black locust (Robinia pseudoacacia L.) in a lignite post-mining area in Germany. Ann. For. Res. 58(1): 39-54.

Abstract. Due to its ability to grow on marginal sites black locust (Robinia pseudoacacia L.) has been widely planted as a short rotation coppice (SRC) system that produce a renewable biomass feedstock in several post-mining areas of East Germany. However, as most of these sites are still in an initial stage of reclamation with low humus and nutrient contents, phosphorous can play a significant role as a plant limiting factor, because legumes require more $P$ than other plants for their development. In April 2011, two experiments were conducted to evaluate the influence of higher rates and different applications of phosphorus fertiliser on the nutrition, survival, and biomass production of two different-aged black locust SRC plantations on the post lignite-mining site "Welzow-Süd", situated in NE Germany. Treatments were applied as triple superphosphate $\left(30,60\right.$ and $\left.120 \mathrm{~kg} \mathrm{P}^{-1}\right)$ and PK fertiliser $(60 \mathrm{~kg} \mathrm{P} \mathrm{ha-1)} \mathrm{through} \mathrm{broadcasting} \mathrm{or} \mathrm{banding} \mathrm{on} \mathrm{recently}$ harvested or planted trees, respectively. Soil, leaf and woody biomass data were analysed utilising the Mann-Whitney U test and the Spearman correlation coefficient $(\mathrm{rS})$. Following two growing seasons, it was observed that the total dry weight yields of the black locust seedlings were increased strongly by up to 8 times when compared to the control group, particularly when TSP was applied through banding. P fertilisation, however, did not affect the biomass yield of six-year-old black locust trees, but P concentration in leaves among treatments of both sites was still significantly increased and sufficient from a quantity upwards of $60 \mathrm{~kg} \mathrm{P} \mathrm{ha}^{-1}$. Taken together, a comparably moderate amount of $\mathrm{P}$ fertiliser $\left(60 \mathrm{~kg} \mathrm{ha}^{-1}\right)$ had a strong impact on $\mathrm{P}$ uptake and growth performance in the examined black locust seedlings, which reveals a high potential to improve the current fertilisation practices for SRC black locust plantations grown on our research site. Keywords biomass yield, black locust, $\mathrm{P}$ fertilisation, post-mining area, reclamation, Robinia pseudoacacia L.

Authors. Michael Kanzler (kanzlmic@b-tu.de), Christian Böhm, Dirk Freese - Chair of Soil Protection and Recultivation, Brandenburg University of Technology, Konrad-Wachsmann-Allee 6, D-03046 Cottbus, Germany.

Manuscript received June 18, 2014; revised November 27, 2014; accepted December 08, 2014; online first January 30, 2015. 


\section{Introduction}

Black locust (Robinia pseudoacacia L.) is a nitrogen-fixing legume, native to southeastern North America and common in the early successional stages (Boring \& Swank 1984). It can greatly improve soil properties in terms of enhanced nitrogen content and availability (Keskin \& Makineci 2009, Rice et al. 2004), higher organic soil matter, organic carbon sequestration, soil structure and quality (Yüksek 2012). In addition, black locust is able to grow both at a fast rate and in a strong manner even under infertile soil conditions that are too poor for other annual or woody crops (Bongarten et al. 1992, Grünewald et al. 2009). As black locust is particularly known for its tolerance to drought stress, its low demand for nitrogen, and due to its ability to provide an additional income to those farmers whose properties are inappropriate for conventional agriculture, it is often planted on marginal sites such as post-mining landscapes (Grünewald et al. 2009). In the Lusatian mining area (Eastern Germany) continuously ongoing opencast mining activities still create a high potential for young reclamation areas in terms of agricultural reutilisation with low water retention capacity, low humus and nutrient contents, where conventional land use systems often fail (Böhm et al. 2011). In contrast, comparatively economical annual yields between up to $10 \mathrm{t}$ dry mass $\mathrm{ha}^{-1}$ can be expected for such areas if the black locust is managed as a short rotation coppice (SRC); though this does depend on site conditions, rotation interval, plant age, coppice maturity and planting layout (Grünewald et al. 2009). Against this background, woody biomass production from fast growing trees in SRC for heat and energy supply is considered to be an alternative land use option for these marginal sites (Bungart \& Hüttl 2001). Currently, more than 45 ha SRC planted with mainly black locust trees have already been established in the post-mining area of the lignite opencast mining site "WelzowSüd", situated in NE Germany. However, de- spite their low requirements for nutrition and site conditions, insufficient phosphorus may reduce their $\mathrm{N}_{2}$-fixation capacity, which could then result in a reduction of the plant's biomass production (Römer \& Lehne 2004). Generally, legumes require more $\mathrm{P}$ than other plants for their root development, as well as the energydriven processes that enhance their symbiotic N-fixation (Gillespie \& Pope 1990b, Marschner \& Marschner 2012), as such P is known as a limiting factor for plant growth (Misra et al. 1998). In this connection, phosphorus plays a significant role due to the fact that in soils it rapidly forms insoluble complexes with cations and is incorporated into the organic matter by microbes (Vance 2001), or is only available outside the rhizosphere (Schachtman et al. 1998). Hence, only the phosphate dissolved in the soil solution is actually available for plants. In unfertilised soils, this concentration ranges from 0.001 to $0.1 \mathrm{mg} \mathrm{P} \mathrm{l}^{-1}$, whereas optimal agricultural plant nutrition requires a phosphate concentration of at least $0.2 \mathrm{mg} \mathrm{P} \mathrm{l}^{-1}$ (Pagel et al. 1982) or between 0.3 and $0.8 \mathrm{mg} \mathrm{P}^{-1}$, which additionally has to be constantly replenished by the mobilisation of $\mathrm{P}$ from the labile pool (Scheffer and Schachtschabel 1998, Mengel and Kirkby 2001). To further ensure an equal

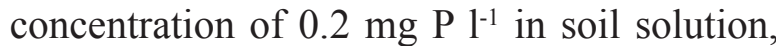
plant-available $\mathrm{P}$ contents $\left(\mathrm{P}_{\mathrm{DL}}\right)$ of approximately $110 \mathrm{mg} \mathrm{P} \mathrm{kg}^{-1}$ in soil is required for carboniferous mine soils due to higher $\mathrm{P}$ sorption and affinity (Freese 1988). Although required plant-available $\mathrm{P}$ contents are expected to be much lower for non-carboniferous substrates, several studies within the Lower Lusatian mining district have indicated insufficient quantities below $15 \mathrm{mg} \mathrm{P} \mathrm{kg}^{-1}$ in non-carboniferous mine soils within the initial stages of reclamation (Vetterlein et al. 1999a, 1999b). This suggests that an adequate $\mathrm{P}$ supply has to be guaranteed by an appropriate use of fertiliser to increase the crop yield and stress-toleration of legume plants, an increase needed in order to ensure a woody biomass renewable energy supply and therefore successful agricultural 
reutilisation of these reclaimed mining areas. Because no common $\mathrm{P}$ fertilisation recommendations to improve growing conditions for black locust previously existed for these sites, it was necessary to close this knowledge gap. The aim of this study was therefore to investigate the field impacts of $\mathrm{P}$ fertilisation rates and forms of application on the tree growth, biomass production, and nutrition of black locust trees in different-aged SRCs growing in a post-mining area. As a result, two experimental sites were established on two mine spoils in divergent stages of reclamation.

\section{Material and methods}

\section{Site description}

The two sites established for the purposes of this study are located in the post-mining area of the lignite opencast mining "Welzow-Süd" (51 35' 58" N, $1416^{\prime} 44^{\prime \prime} \mathrm{O}$ ) in the state of Brandenburg, Germany (Figure 1).

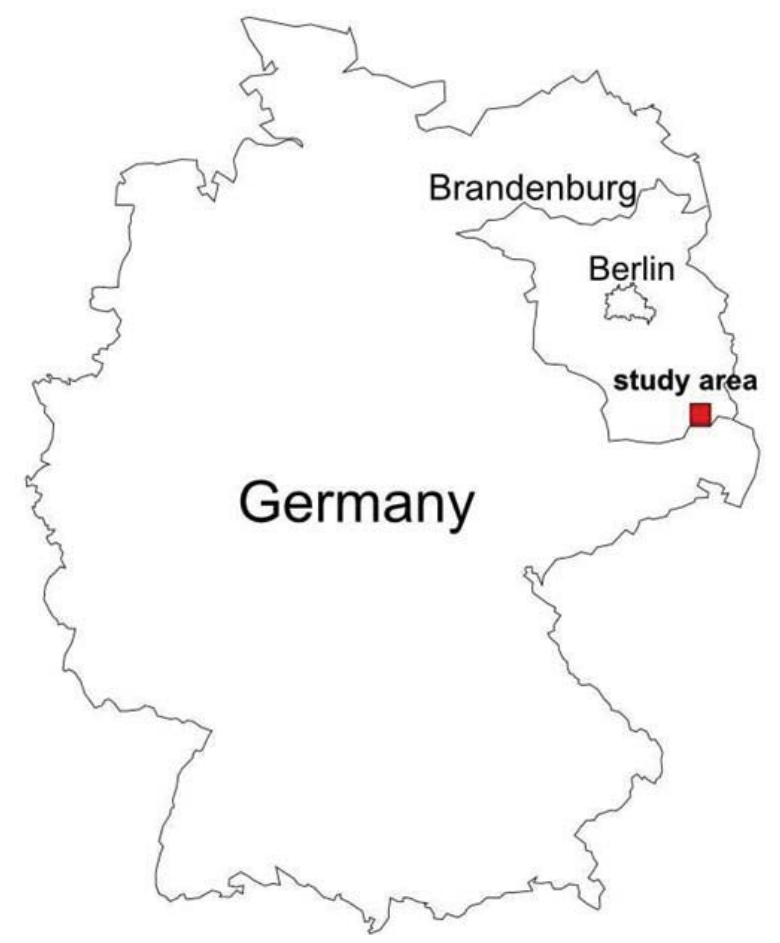

Figure 1 Location map showing the study area in East Germany
Welzow-Süd belongs to a region of Germany which is influenced by a continental climate. With a mean annual temperature of $9.3^{\circ} \mathrm{C}$ and an average annual precipitation sum of 560 mm covering the period of 1951-2003 (meteorological station Cottbus), this post mining site is one of the driest areas in Germany. Two main types of substrates can be identified here: lignite- and pyrite-containing substrates stemming from Tertiary sediments, and lignite- and pyrite-free substrates from Quaternary sediments (Schaaf 2001). Common characteristics are a mainly sandy texture, a low-content of recent organic matter, and a low-nutrient status (Grünewald et al. 2009, Wilden et al. 1999). In both study sites, the dominant soil texture at the topsoil level is loamy sand and mainly consists of pyrite-free substrates from Quaternary sediments. Generally, soil formation is in an initial stage and the soil structures are still instable. The whole research area is not groundwater influenced and was partially reforested with mainly black locust trees at a density of approximately 9,200 trees each hectare (Böhm 2012).

\section{Experimental design and sampling methods}

The research was carried out in the autumn of 2011 in two black locust SRCs which were chosen for a randomised fertilisation experiment. The first experiment took place in a six-year-old coppice (site A) which had been recently harvested and was already in the second rotation, while the second trial was carried out in a recently established plantation (site B). The randomised block design consisted of 25 blocks with different fertilisation levels and treatments, all with five replications each. Plot size was around $160 \mathrm{~m}^{2}$, but only the inner area of approximately $64 \mathrm{~m}^{2}$ was sampled and used as a treatment zone to avoid boundary or carry-over effects. Depending on plant density, approximately 60 trees covered the treatment area. Triple superphosphate (TSP, $46 \% \mathrm{P}_{2} \mathrm{O}_{5}$ ) was used as a basic source of phosphorus, but 
additional variations with a PK-fertiliser $(15 \%$ $\left.\mathrm{P}_{2} \mathrm{O}_{5}, 30 \% \mathrm{~K}_{2} \mathrm{O}\right)$ were also realised and applied manually by hand. P-treatment levels in the first experiment were $0,30,60$ and $120 \mathrm{~kg}$ $\mathrm{ha}^{-1}$ of elemental P broadcasted as TSP and 60 $\mathrm{kg} \mathrm{ha}^{-1}$ added as PK-fertiliser (Figure 2). The treatments at the second site did not differ in the amount of phosphorus which was given (60 $\mathrm{kg} \mathrm{ha}^{-1}$ each), but did in relation to the form of application and P source, in which PK and TSP were either broadcasted or banded. Both sites were treated in April 2011, as fertiliser was applied to the recently harvested (site A) and planted (site B) trees, respectively. In order to adjust the nutrition with potassium, and to accelerate phosphorus uptake by the plant (Römer \& Lehne 2004), all plots were additionally treated with potassium oxide $\left(\mathrm{K}_{2} \mathrm{O}\right)$ to a level of $180 \mathrm{~kg}$ elemental $\mathrm{K} \mathrm{ha}^{-1}$ each. In order to take into account the ability of legumes to fix atmospheric nitrogen, as well as to save resources and prevent possible $\mathrm{N}$ leaching into deeper spoil layers on non-carboniferous sandy mine spoils (Vetterlein et al. 1999a), any donation of mineral nitrogen fertiliser was avoided.

Soil and Leaf Sampling. Soil samples for the analyses of chemical properties were taken on $20^{\text {th }}$ April 2011, immediately before fertilisation, and also four months after. Considering the fact that topsoil is the most fertile and important layer for plant growth (Antonijevic et al. 2012), sampling was performed up to a depth of $30 \mathrm{~cm}$. For each of the 50 plots, composite samples of 8 cores were taken. Samples were instantly stored in a freezer pack and directly transported to the laboratory. Leaf samples were taken in August as a composite sample of five leaflets from the lower and middle crown (three from the sunny and two from shadowed canopy) of five randomly chosen, average individuals from each plot in each site. Sampled trees were marked for further research.

Tree Growth Measurements and Survival Rate. The tree height and shoot basal diameter (SBD) at $10 \mathrm{~cm}$ from the ground soil of the surviving trees were measured annually in winter 2011/12 and 2012/13, respectively. Within the treatment area of each plot, 24 leaf-

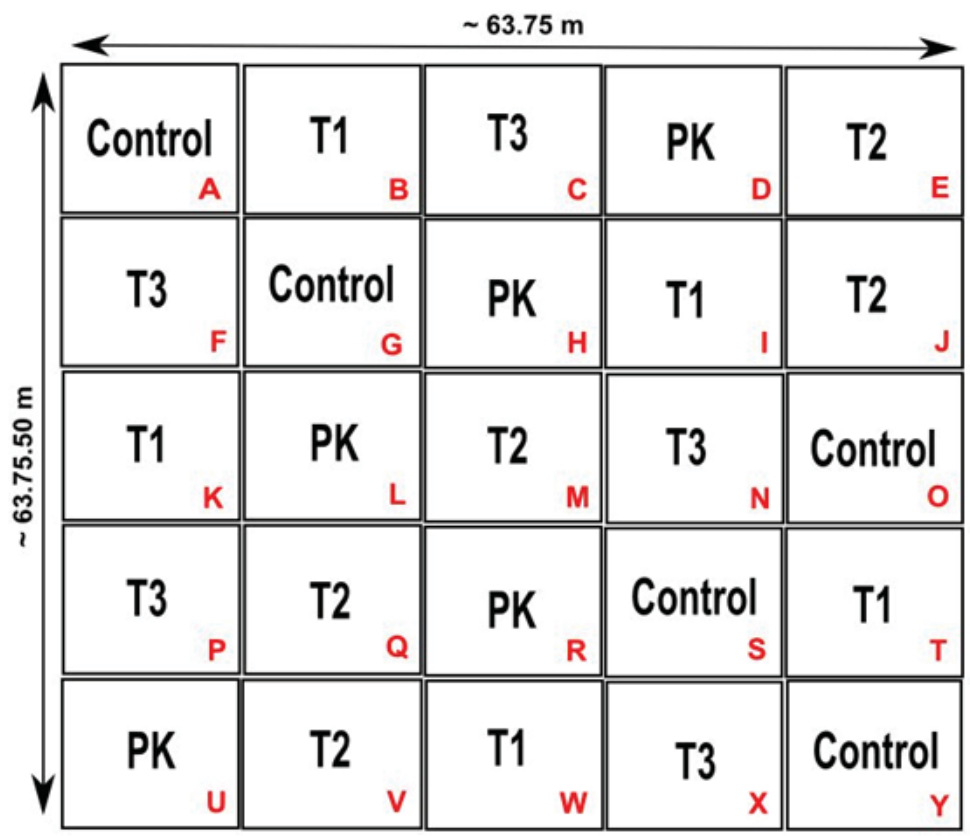

Figure 2 Randomized block design on site $\mathrm{A}$ with 5 treatments levels and a control group. Treatments are 30 (T1), 60 (T2) and 120 (T3) $\mathrm{kg} \mathrm{P} \mathrm{ha}^{-1}$ as triple superphosphate and $60 \mathrm{~kg} \mathrm{P} \mathrm{ha}^{-1} \mathrm{PK}$ fertiliser (PK) 
less trees (every third tree in each row with a treatment zone containing six rows) were measured, whereas all individuals within the treatment zone were considered in order to aid in determining the survival rate. The woody above-ground dry biomass for each plot was predicted with an allometric equation according to Böhm et al. (2011) and later projected for each treatment in hectares. The mortality rate was not included for yield prediction due to its suspected independence from $\mathrm{P}$ fertilisation.

\section{Chemical analysis}

The soil contents of nitrate nitrogen and ammonium nitrogen $\left(\mathrm{NO}_{3}-\mathrm{N}, \mathrm{NH}_{4}-\mathrm{N}\right)$ were extracted and analysed according to DIN ISO 14256. Following this, the soil samples were then air-dried, homogenised and sieved $\leq 2$ $\mathrm{mm}$. Soil $\mathrm{pH}$ was measured in $0.01 \mathrm{~mol} \mathrm{~L}^{-}$ ${ }^{1} \mathrm{CaCl}_{2}$ solution (soil solution ratio $=1: 2.5$ ). Plant-available phosphorus $\left(\mathrm{P}_{\mathrm{DL}}\right)$ and potassium $\left(\mathrm{K}_{\mathrm{DL}}\right)$ were determined according the VDLUFA DL-method (Hoffman 1991). Foliage was oven-dried at $60{ }^{\circ} \mathrm{C}$ until the weight was constant before it was later grinded using a vibratory disc mill. The total contents of carbon (TC) and nitrogen (TN) for all plant and soil samples were measured with an ELEMENTAR VARIO III element analyzer. Soil organic content was estimated by the loss-on-ignition (LOI) method after igniting the soil samples at $450{ }^{\circ} \mathrm{C}$ in a muffle furnace for five hours (Barrington et al. 1994). After, carbon was measured again (TIC) and the TOC was calculated by the difference of TC and TIC. Phosphorus, potassium, magnesium and calcium in digested plant materials were diagnosed according to Schramel et al. (1993) using inductively coupled plasma spectrometry (ICP-AES - Unicam iCAP6000 Duo).

\section{Statistical analysis}

Statistical analysis was performed using IBM
SPSS 21 (August 29 $9^{\text {th }}, 2012$ ) software. All variables were tested for normal distribution using the Shapiro-Wilk-Test (W-test). Considering the fact that several individual variants (treatments) were not normally distributed, we used the non-parametric Kruskal-Wallis test $(\mathrm{H}-$ test) to identify any influence of the treatments on other tested parameters. Subsequently, the Mann Whitney test (U-Test) was applied to detect the pairwise differences. In order to evaluate the variations between soil nutrients among treatments before and after fertilisation, we utilised the Wilcoxon sign rank test. Furthermore, the Spearman correlation coefficient $(r S)$ was computed to express relationships between different soil, leaf and biomass properties. The minimal significance level $(\alpha)$ for rejection of the null hypothesis was 0.05 .

\section{Results}

\section{Chemical soil properties}

The first soil analysis of April 2011 revealed comparable alkalescent soil $\mathrm{pH}$ values among treatments for site A (Table 1) and small variations in acidic values between 5.8 and 6.5 for the B site. As expected, soil contents of plantavailable nutrients before the fertilisation of both sites were generally very low. However, it should be noted that the nutrient status for banded treatments should be taken with caution as the fertiliser was concentrated in slim lines along the tree rows, due to sampling points being distributed randomly in the whole treatment area.

Soil analysis after fertilisation (August 2011) showed that the concentrations of mineralised $\mathrm{N}$ among all treatments of both sites declined, while available soil $\mathrm{P}$ increased significantly for all plots on both sites which were treated with at least $60 \mathrm{~kg} \mathrm{P}^{-1}$ broadcasted TSP. Extractable $\mathrm{K}$ in soil significantly increased ( $p<$ 0.05 ) only in banded PK fertilised groups (RS). The total content of nitrogen (TN) was similar 
among treatments and sites, except for Control at site A. Overall, low total carbon (TC) pools between 0.45 and $0.67 \%$ were detected, whereas contents for site A were up to $49 \%$ higher than those of site B. This contrasted sharply with the total organic carbon contents (TOC), as the values for site $\mathrm{B}$ were almost twice the value of those detected on site $\mathrm{A}$. $\mathrm{C} / \mathrm{N}$ ratios between 23 and 27 occurred at site $\mathrm{A}$, whereas slightly wider ratios with values around 30 were determined for site B. repetitions diverged widely. Yet, even taking this into account, no significant differences in the contents of the aforementioned elements among treatments were detected.

As had been expected, the foliar P content on site A steadily increased with higher fertiliser rates $(r=0.629, p<0.01)$ and reached its zenith at T3. Thus, though foliage $\mathrm{P}$ of Control was significantly lower than all other treatments, no significant increase upwards of a quantity of $60 \mathrm{~kg} \mathrm{P} \mathrm{ha}^{-1}$ occurred. $\mathrm{N}$ detected in

\section{Plant nutrition}

While foliar $\mathrm{N}$ and $\mathrm{K}$ contents among TSP $30 \mathrm{~kg} \mathrm{P} \mathrm{ha}^{-1}$ (T1), TSP $120 \mathrm{~kg} \mathrm{P}$ $\mathrm{ha}^{-1}$ (T3) and PK $60 \mathrm{~kg}$ broadcasted $\mathrm{P} \mathrm{ha}^{-1}(\mathrm{PK})$ at site A were comparable, TSP $60 \mathrm{~kg} \mathrm{P} \mathrm{ha}^{-1}$ (T2) tree leaves contained approximately $37 \%$ more $\mathrm{N}$ than those of Control (Figure 3). Conversely, Control trees accumulated $27 \%$ more $\mathrm{K}$ than those of $\mathrm{T} 2$. However, the largest amounts of $\mathrm{Ca}$ and $\mathrm{Mg}$ were accumulated in the foliage of trees on $\mathrm{T} 3$. The lowest $\mathrm{Mg}$ and $\mathrm{Ca}$ contents were determined for $\mathrm{T} 2$, but the adjacent values for the

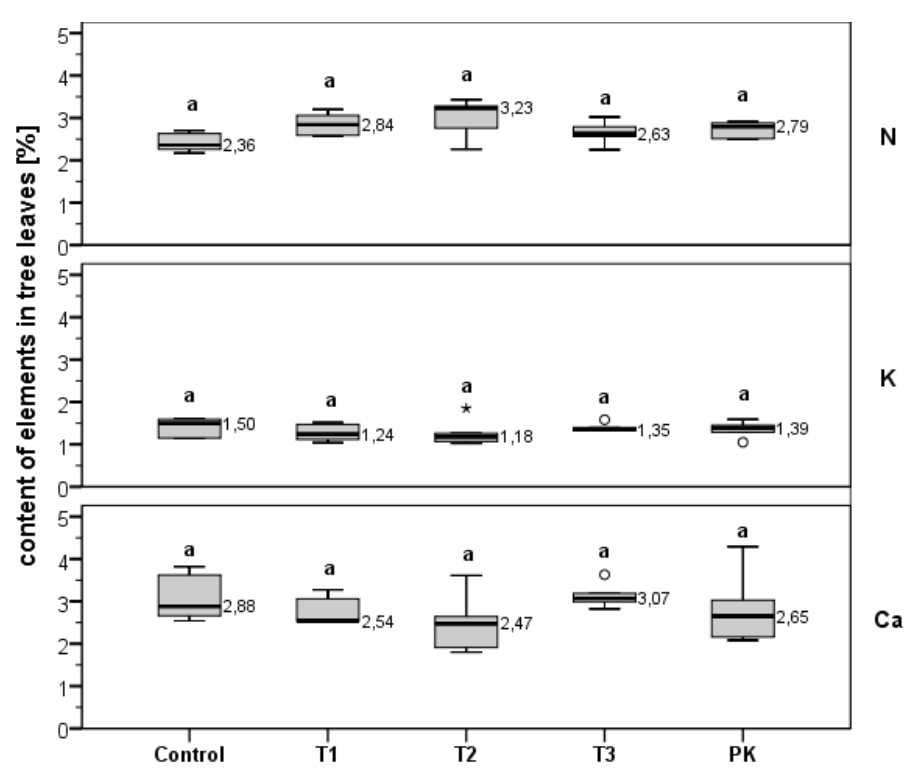

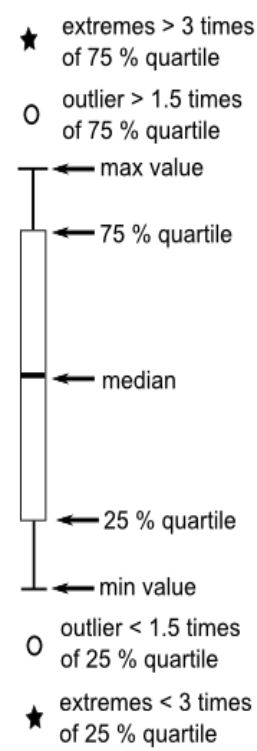

Figure 3 Contents of nutrient elements in tree leaves among treatments on site A. Different letters indicate a significant difference $(p<0.05)$ among different treatments 
Table 1 Soil chemical characteristics $(0-30 \mathrm{~cm}$ depth) among different treatments upon both study sites before and after fertilisation

\begin{tabular}{|c|c|c|c|c|c|c|c|c|c|c|c|c|c|}
\hline \multirow{3}{*}{ site } & \multicolumn{5}{|c|}{ April 2011} & \multicolumn{8}{|c|}{ August 2011} \\
\hline & treatment & $\mathrm{pH}$ & $\mathrm{N}_{\text {min }}$ & $\mathrm{P}_{\mathrm{DL}}$ & $\mathrm{K}_{\mathrm{DL}}$ & $\mathrm{pH}$ & $\mathrm{TN}$ & $\mathrm{TC}$ & TOC & $\mathrm{C} / \mathrm{N}$ & $\mathrm{N}_{\min }$ & PDL & KDL \\
\hline & & & \multicolumn{4}{|c|}{$\mathrm{mg} \mathrm{kg}^{-1}$ soil } & \multicolumn{3}{|l|}{$\%$} & ratio & \multicolumn{3}{|c|}{$\mathrm{mg} \mathrm{kg}^{-1}$ soil } \\
\hline \multirow{5}{*}{ A } & $\mathrm{C}$ & $7.8^{\mathrm{a}}$ & $3.7^{\mathrm{a}}$ & $17.0^{\mathrm{a}}$ & $31.0^{\mathrm{a}}$ & $7.8^{\mathrm{a}}$ & $0.02^{\mathrm{a}}$ & $0.60^{\mathrm{a}}$ & $0.29^{\mathrm{a}}$ & $25 a$ & $1.3^{\mathrm{a}}$ & $19.0^{\mathrm{a}}$ & $32.0^{\mathrm{a}}$ \\
\hline & $\mathrm{T} 1$ & $7.9^{\mathrm{a}}$ & $4.3^{\mathrm{a}}$ & $14.0^{\mathrm{a}}$ & $29.0^{\mathrm{a}}$ & $7.8^{\mathrm{a}}$ & $0.01^{\mathrm{a}}$ & $0.67^{\mathrm{a}}$ & $0.27^{\mathrm{a}}$ & $23 a$ & $1.6^{\mathrm{a}}$ & $17.0^{\mathrm{a}}$ & $34.0^{\mathrm{a}}$ \\
\hline & $\mathrm{T} 2$ & $7.8^{\mathrm{a}}$ & $4.3^{\mathrm{a}}$ & $16.0^{\mathrm{a}}$ & $31.0^{\mathrm{a}}$ & $7.7^{\mathrm{a}}$ & $0.01^{\mathrm{a}}$ & $0.51^{\mathrm{a}}$ & $0.24^{\mathrm{a}}$ & $27 \mathrm{a}$ & $1.8^{\mathrm{a}}$ & $26.0^{\mathrm{a}}$ & $35.0^{\mathrm{a}}$ \\
\hline & $\mathrm{T} 3$ & $7.8^{\mathrm{a}}$ & $4.1^{\mathrm{a}}$ & $15.0^{\mathrm{a}}$ & $37.0^{\mathrm{a}}$ & $7.8^{\mathrm{a}}$ & $0.01^{\mathrm{a}}$ & $0.59^{\mathrm{a}}$ & $0.26^{\mathrm{a}}$ & $25 \mathrm{a}$ & $2.0^{\mathrm{a}}$ & $23.0^{\mathrm{a}}$ & $32.0^{\mathrm{a}}$ \\
\hline & PK & $7.9^{\mathrm{a}}$ & $3.7^{\mathrm{a}}$ & $13.8^{\mathrm{a}}$ & $35.0^{\mathrm{a}}$ & $7.8^{\mathrm{a}}$ & $0.01^{\mathrm{a}}$ & $0.63^{\mathrm{a}}$ & $0.25^{\mathrm{a}}$ & $23 \mathrm{a}$ & $2.1^{\mathrm{a}}$ & $17.0^{\mathrm{a}}$ & $41.0^{\mathrm{a}}$ \\
\hline \multirow{5}{*}{ B } & $\mathrm{C}$ & $6.3^{\mathrm{a}}$ & $2.0^{\mathrm{a}}$ & $4.4^{\mathrm{a}}$ & $26.0^{\mathrm{a}}$ & $6.6^{\mathrm{a}}$ & $0.01^{\mathrm{a}}$ & $0.50^{\mathrm{a}}$ & $0.41^{\mathrm{a}}$ & $32 a$ & $1.1^{\mathrm{a}}$ & $3.3^{\mathrm{a}}$ & $21.0^{\mathrm{a}}$ \\
\hline & TB & $5.8^{\mathrm{a}}$ & $1.9^{\mathrm{a}}$ & $2.9^{\mathrm{a}}$ & $25.0^{\mathrm{a}}$ & $5.4^{\mathrm{a}}$ & $0.01^{\mathrm{a}}$ & $0.54^{\mathrm{a}}$ & $0.45^{\mathrm{a}}$ & $28 \mathrm{a}$ & $1.3^{\mathrm{a}}$ & $21.0^{\mathrm{b}}$ & $19.0^{\mathrm{a}}$ \\
\hline & TS & $6.0^{\mathrm{a}}$ & $1.6^{\mathrm{a}}$ & $4.9^{\mathrm{a}}$ & $19.0^{\mathrm{a}}$ & $6.6^{\mathrm{a}}$ & $0.01^{\mathrm{a}}$ & $0.45^{\mathrm{a}}$ & $0.39^{\mathrm{a}}$ & $26 a$ & $1.1^{\mathrm{a}}$ & $20.0^{\mathrm{ab}}$ & $20.0^{\mathrm{ac}}$ \\
\hline & $\mathrm{RB}$ & $6.4^{\mathrm{a}}$ & $1.7^{\mathrm{a}}$ & $3.8^{\mathrm{a}}$ & $17.0^{\mathrm{a}}$ & $7.3^{\mathrm{a}}$ & $0.01^{\mathrm{a}}$ & $0.50^{\mathrm{a}}$ & $0.36^{\mathrm{a}}$ & $31 \mathrm{a}$ & $1.2^{\mathrm{a}}$ & $20.0^{\mathrm{b}}$ & $45.0^{\mathrm{b}}$ \\
\hline & $\mathrm{RS}$ & $6.5^{\mathrm{a}}$ & $1.7^{\mathrm{a}}$ & $3.9^{\mathrm{a}}$ & $19.0^{\mathrm{a}}$ & $6.0^{\mathrm{a}}$ & $0.01^{\mathrm{a}}$ & $0.50^{\mathrm{a}}$ & $0.36^{\mathrm{a}}$ & $36 a$ & $1.0^{\mathrm{a}}$ & $6.7^{\mathrm{ab}}$ & $46.0^{\mathrm{bc}}$ \\
\hline
\end{tabular}

Note. Values are given as median of a subset of plots $(\mathrm{n}=5)$. Treatments on A site are: $30(\mathrm{~T} 1), 60(\mathrm{~T} 2)$ and $120 \mathrm{~kg} \mathrm{Pha}^{-1}$ (T3) applied as triple superphosphate and $60 \mathrm{~kg}$ P ha-1 applied as PK fertiliser (PK). On site B plots were treated with $60 \mathrm{~kg} \mathrm{P} \mathrm{ha}^{-1}$ as triple superphosphate through broadcasting (TB), banding (TS) and as PK fertiliser broadcasted (RB) and banded (RS). Different letters indicate a significant difference $(p<0.05)$ among values within a column of each site separately. Bold printed values indicate a significant change between sampling dates of a single parameter among treatments at the $p<0.05$ level.

tree leaves of the B site in most cases was up to $57 \%$ higher than those at the A site (Figure 4) and correlates closely with the $\mathrm{P}$ foliage content $(r=0.745, p<0.01)$. PK $60 \mathrm{~kg}$ broadcasted $\mathrm{P} \mathrm{ha}^{-1}(\mathrm{RB})$ and $\mathrm{RS}$ accumulated the highest amount of $\mathrm{N}$ and were significantly different from those of Control and TSP $60 \mathrm{~kg}$ broadcasted $\mathrm{P} \mathrm{ha}^{-1}$ (TB) $(p<0.05)$, while remaining treatments had almost comparable $\mathrm{N}$ contents. Contrary to the results of site A, treatments significantly increased the foliage $\mathrm{N}$ content in tree leaves of black locust seedlings $(r=0.700$, $p<0.01$ ). In addition, foliage of RB and RS contained the highest amounts of $\mathrm{K}$ but were low in $\mathrm{Mg}$, whereas a negative relationship between $\mathrm{K}$ and $\mathrm{Mg}$ among all treatments could be observed $(r=-0.770, p<0.01)$. On the other hand, foliage $\mathrm{Ca}$ and $\mathrm{Mg}$ were positively related to each other $(r=0.802, p<0.01$ site $\mathrm{A}$, $r=0.506, p<0.01$ site B) on both sites.

Foliar P among treatments of the B site was correlated to the amount of added phosphorus and the form of application, respectively ( $r=$ $0.581, p<0.01)$. Overall, P contents were comparable to those of site A and, except for the $\mathrm{TB}$, significantly higher than the control group $(p<0.05)$. This was particularly pronounced between Control and banded treatments $(p<$ $0.01)$.

\section{Biomass yield and survival rate}

The biomass yields among different treatments on site A for both measuring periods are given in Figure 5. In both years, trees in Control plots achieved the highest biomass yield, while T3 provided only average results.

In early spring 2012, the first signs of a devastating fungal disease appeared over the entire study site A. As a result, woody biomass declined for several treatments, as did T2 where dry woody biomass was approximately $26 \%$ lower than in the previous year. PK and T3 had barely noticeable biomass increases of not more than $2 \%$, while those trees of T1 marked a surplus of at least $8 \%$. With a surplus of $13 \%$, Control did substantially better, yet no statistical yield differences among treatments were evident. In contrast, Figure 6 reveals significantly higher dry woody biomass for all treatments of site B when compared to Control (banded treatments $p<0.01$, broadcasted 
treatments $p<0.05$ ) at the end of 2011.

In addition, the maximum biomass yield was more than 8 times higher than Control when TSP was applied by banding. Likewise, it was significantly higher $(p<0.01)$ than TB and RB $(p<$ $0.05)$. Thankfully TS, RS and RB produced favourable results, as TB was below expectations. In the following growing season (2012), TS trees sextupled their crop yield and remained the most profitable among all tested treatments on site B. Additionally, the average biomass yield of RS, which was merely ordinary at the end of the growing season of 2011, now increased more than eightfold and thus achieved the second-best result. Taken together, biomass yields of all banded treatments were substantially higher than at broadcasted groups after two years and thereby drew near to the performance of those black locust trees at site A which were five years older. Furthermore, the biomass yield in 2012 and 2013 for black locust trees on site $B$ correlate closely with the $\mathrm{P}$ leaf concentration $(r=0.656, p<0.01$ in 2012, $r=0.661, p<0.01$ in 2013), the $\mathrm{N}$ leaf concentration $(r=0.537, p<0.01$ in 2012, $r=$ $0.513, p<0.01$ in 2013) and the $\mathrm{P}$ application rate $(r=0.541, p<$ 0.01 in 2012, $r=0.557, p<0.01$ in 2013). By contrast, for site A only leaf $\mathrm{N}$ was significantly correlated with the biomass yield in 2013 ( $r$ $=-0,526, p<0.01)$.

On average, every fifth tree on site A and less than each tenth tree on site B, died within the first growing season (2011). In the following year it was already each forth tree that died
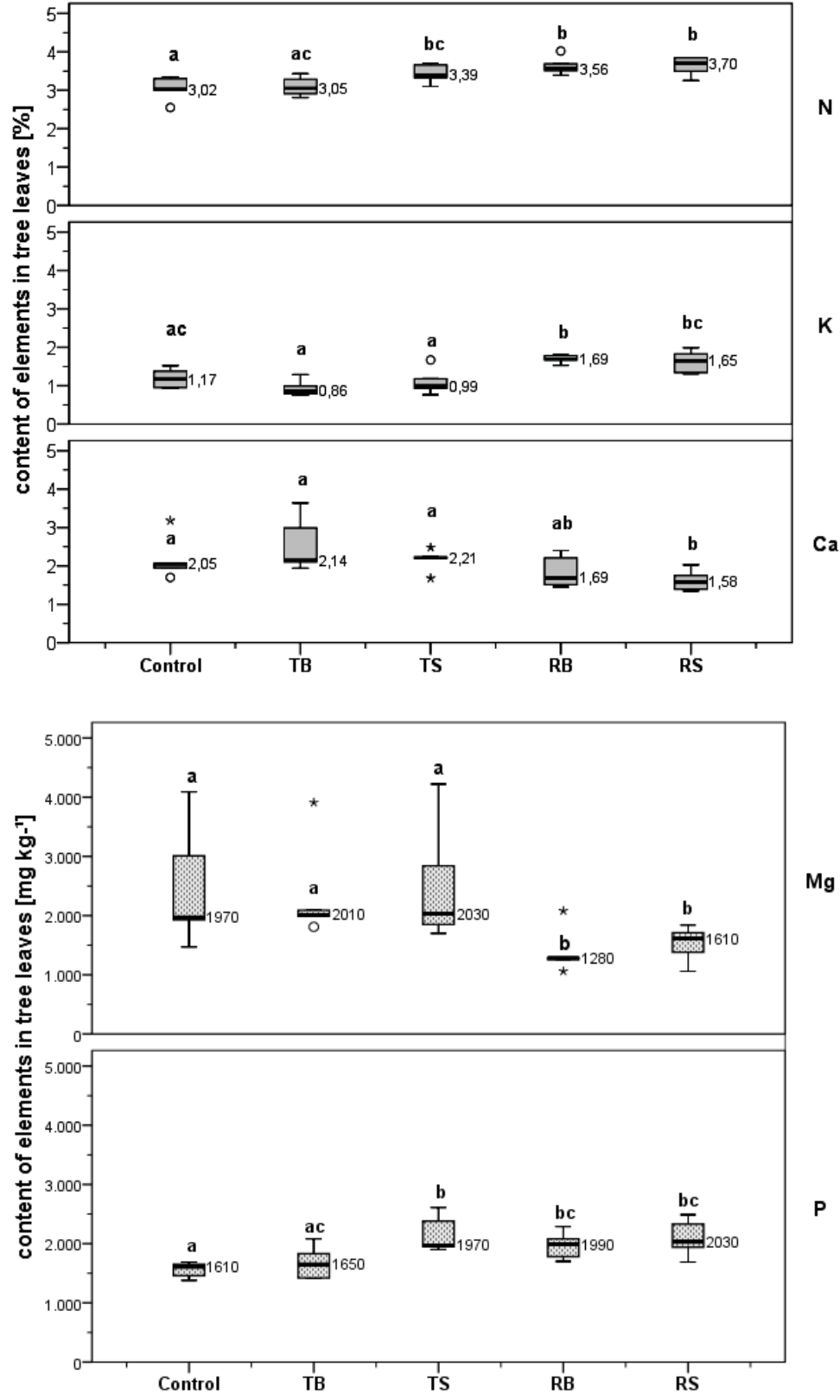

Figure 4 Contents of nutrient elements in tree leaves among treatments for site B. Different letters indicate a significant difference $(p<0.05)$ among different treatments

on site A, whereby T1 lost the highest (28\%) and Control the lowest number (20\%) of trees. Meanwhile, losses on our second experimental trail were hardly noticeable (lower than 4\%). Yet, it should be noted that differences in loss rates among treatments on both sites were not statistically significant. 


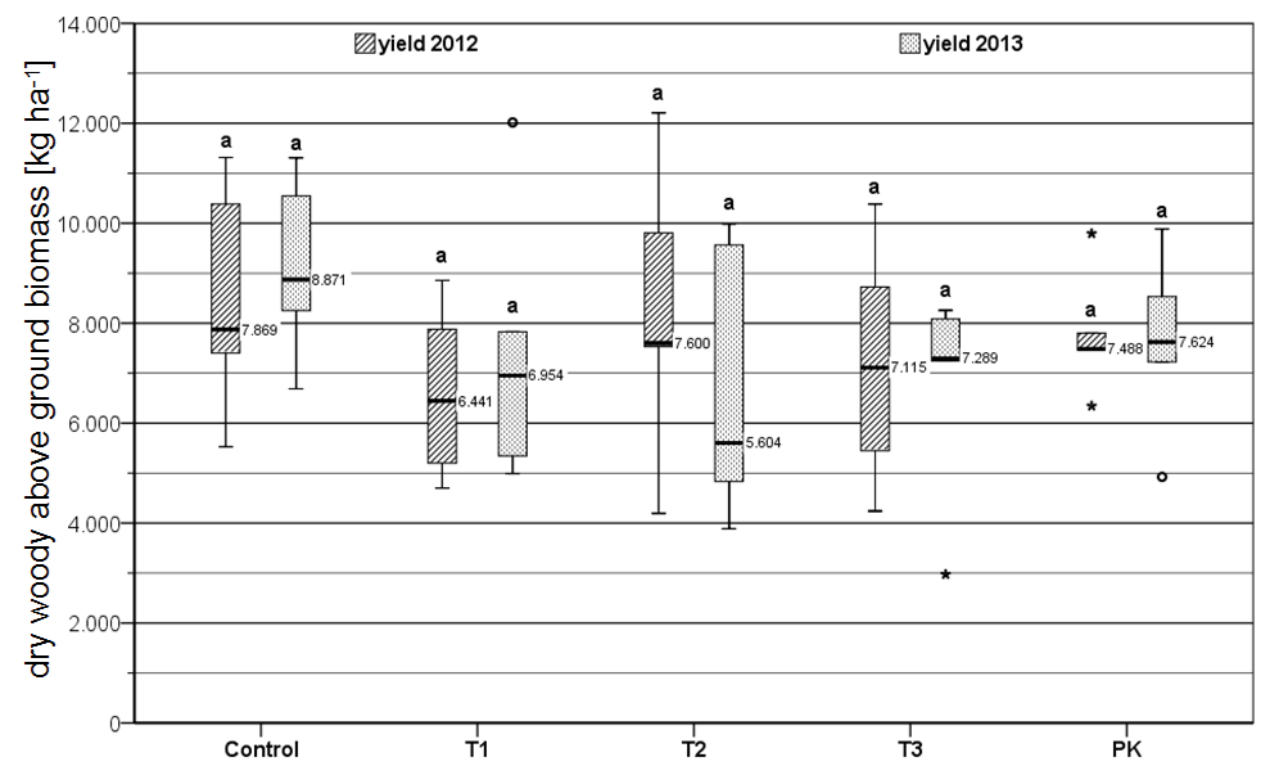

Figure 5 Total dry biomass for each treatment on site A for growing season 2011 and 2012. Values are median weights of a subset of plots $(\mathrm{n}=5)$. Different letters indicate significant differences $(p<0.05)$ between treatments within a year

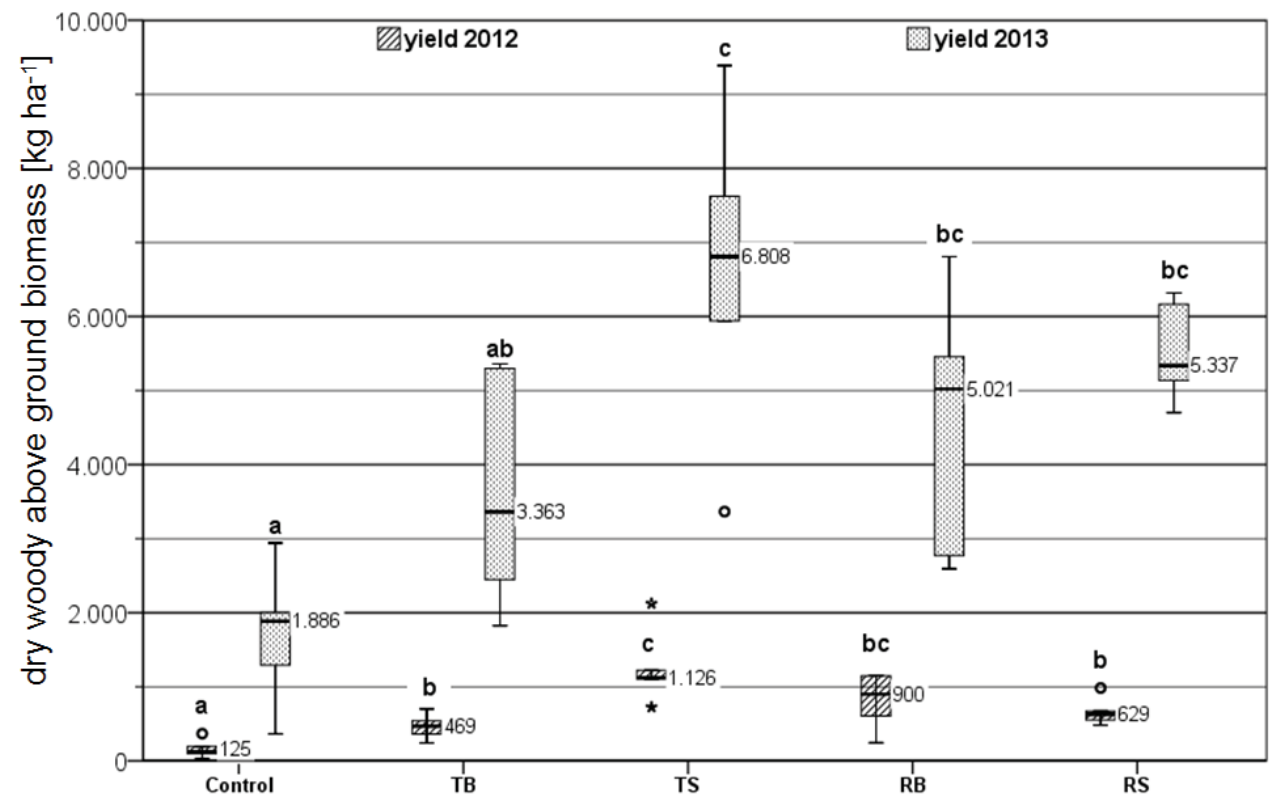

Figure 6 Total dry biomass for each treatment on site B for growing season 2011 and 2012. Values are median weights of a subset of plots $(\mathrm{n}=5)$. Different letters indicate significant differences $(p<0.05)$ between treatments within a year

\section{Discussion}

\section{P fertilisation and crop yield response}

Soil analysis from April 2011 indicated very low amounts of plant-available nutrients and organic matter content in the topsoil of both study sites. This has, however, been reported as usual for mine spoils in the Lusatian lignite region (Heinsdorf 1992, Katzur \& Hanschke 
1990, Vetterlein et al. 1999a, 1999b). As such, most of these areas are less suitable for agricultural crop production or require high fertilisation rates during the first years of reclamation (Katzur \& Hanschke 1990). In fact, our findings confirm that even under these infertile soil conditions, black locust trees grown in Control group plots were able to achieve at least $4.4 \mathrm{t}$ ha $^{-1} \mathrm{a}^{-1}$ (site A) and $0.9 \mathrm{t} \mathrm{ha}^{-1} \mathrm{a}^{-1}$ (site B) of dry woody biomass within a period of two growing seasons. Although higher $\mathrm{P}$ fertilisation rates could not clearly improve biomass production at site A, banded TSP treatments at site B led to an average increase of approximately 8 times more woody dry biomass when compared to their control counterparts within the first growth period. After two growing periods, it was ascertained that yields of banded trees were superior to broadcasted trees. Therefore we can assume that, in addition to the type of fertiliser, the form of application can additionally improve the fertiliser use efficiency, which is also suggested by Brown \& van den Driessche (2005) and Vetterlein et al. (1999a). In analogy to the results of Ntayombya \& Gordon (1995), black locust seedlings performed well under PK fertilised conditions, even without any mineral nitrogen donations and under initial soil conditions. The lack of yield response to $\mathrm{P}$ fertilisation on site $\mathrm{A}$, however, might have been caused by several reasons. First of all, the devastating fungal disease, primarily Fusarium spp. and Phomopsis oncostoma (Thüm.) Höhn. (Landgraf \& Hydeck 2014), which initially appeared in Spring 2012, obscured any growth effects by destroying above-ground biomass, an occurrence particularly noticeable on those plots which had been fertilised. Secondly, the highest above-ground biomass yield and tree survival rate was determined in the control group, probably favoured by comparatively good preconditions in terms of soil TN and plant-available $\mathrm{P}$ and $\mathrm{K}$.

\section{P fertilisation and plant nutrition}

Finally, and probably a key reason for a lack of response to $\mathrm{P}$ fertilisation, is that phosphorus was not a primary growth limiting element. Nevertheless, the amount of $\mathrm{P}$ fertiliser or form of application significantly increased the $P$ content in foliage on both sites. Overall, foliage $\mathrm{P}$ concentration increased by up to $69 \%$ (site A) and $25 \%$ (site B) within the first vegetation period after fertilisation. Similar results were also obtained with different pine species, black locust and other legumes (Abarchi et al. 2009, Crous et al. 2008, Flinn et al. 1982, Reinsvold and Pope 1987). Leaf analysis additionally indicated an increase of $\mathrm{N}$ by up to $37 \%$ (site A) and almost $23 \%$ (site B) when compared to their control counterparts. Although there was no significant correlation between $\mathrm{P}$ application and $\mathrm{N}$ foliar content for site $\mathrm{A}$, this correlation was present for site $\mathrm{B}$. These results are in conformity with the findings of Pope and Andersen (1982), who explained the enhanced foliar $\mathrm{N}$ content through the stimulating effect on the nitrogen-fixing bacteria in $\mathrm{P}$ fertiliser application. Alternatively, the atmospheric deposition is also conceivable as an additional nitrogen source, especially for younger, frugal plants. In addition, black locust itself acts as a nitrogen source through leaf and root litter mineralisation and nitrification and can therefore generate up to $75 \mathrm{~kg} \mathrm{~N} \mathrm{ha}^{-1}$ (Boring \& Swank 1984). In addition, Heinsdorf (1987) indicated that the $\mathrm{N}$ uptake of black locust plants can be stimulated through a combination of $\mathrm{P}$ and $\mathrm{K}$ fertilisation, as an admixture of $\mathrm{N}$ results in a considerably reduced growth and therefore must be avoided at any rate. In fact, black locust seedlings require minimal amounts of nitrogen, at least initially, to support nodulation and thereby N2 fixation (Reinsvold \& Pope 1987). Conversely, lower mineral N pool in soil, and higher $\mathrm{N}$ demands of plants with an already established root system, could be responsible for the negligible $\mathrm{N}$ accumulation in the foliage of fertilised trees at our first study 


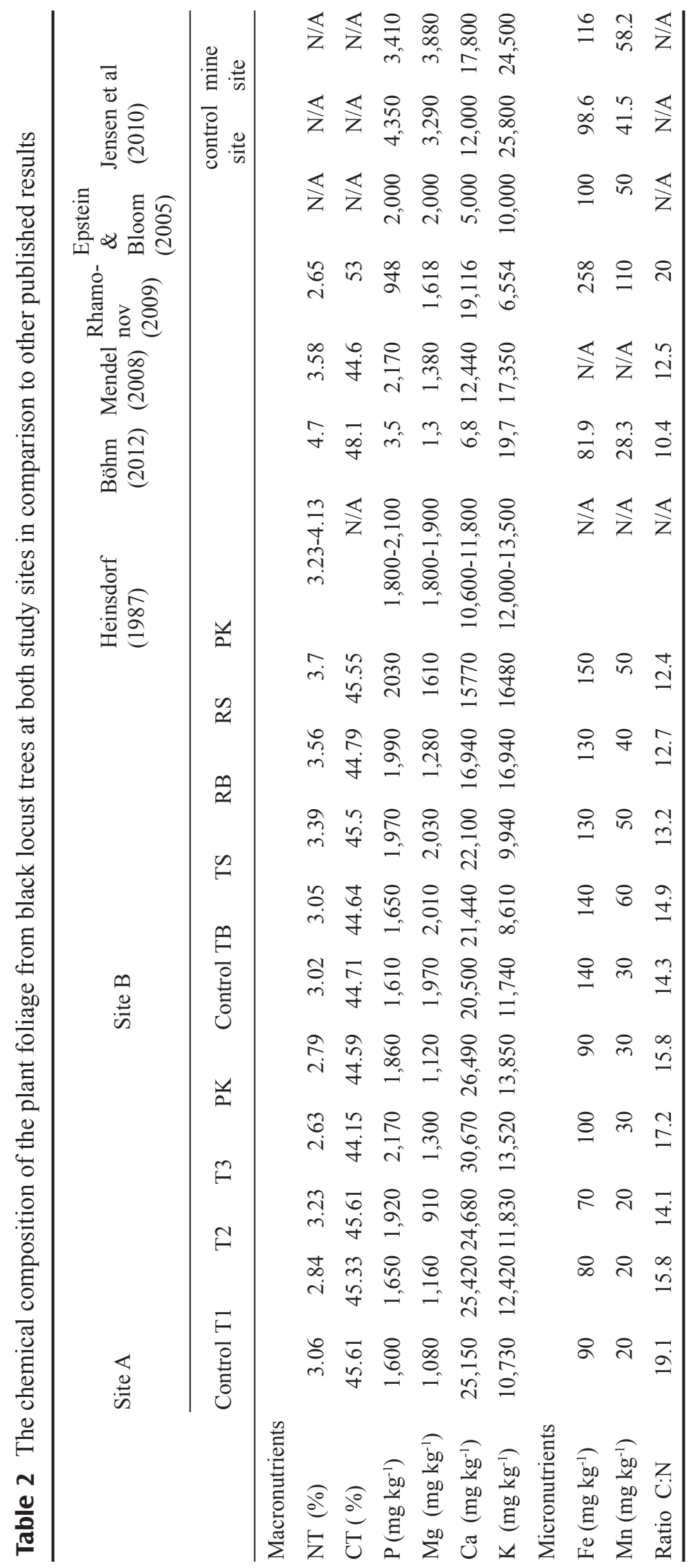


site. On the other hand, the decline in nutrient contents of legumes with age is caused by advancing cell-wall formations, a decreasing leaf/steam ratio, increasing proportions of senescent plant parts, and translocation of $\mathrm{N}$ and $\mathrm{P}$ from the leaves and stems to inflorescences (Abarchi et al. 2009). Nonetheless, soil available $\mathrm{N}$ pool should not be overestimated since, with increasing tree size and $\mathrm{N}$ demand, the soil source becomes secondary to enhanced supply through nitrogen fixation (Bongarten et al. 1992). Furthermore, the nitrogen fixation rate is often suppressed by increased $\mathrm{N}$ availability through fertilisation while also being frequently stimulated by increased $\mathrm{P}$ availability (Reed et al. 2007). A direct comparison of our leaf nutrient results to other studies with black locust (Table 2) clearly shows that, even without additional mineral applications and despite low soil available $\mathrm{N}$ supply, $\mathrm{N}$ foliage contents indicate a sufficient nutrient status. A similar situation occurred for leaf $\mathrm{P}$ content, at least for most of the fertilised treatments. In their control counterparts, however, the P levels were lower than in the majority of comparative studies. Nevertheless, those concentrations were still sufficient, since leaf contents of healthy woody plants are between 0.1 to $0.7 \%$ of dry weight (Aiello \& Graves 1996 , Smith 1978) and substantially lower values for a restriction in $\mathrm{P}$ nutrient supply on mine spoils were reported by Heinsdorf (1992). Despite this fact, $\mathrm{P}$ fertilisation still seems to be appropriate in order to exclude phosphorus as a yield restricting factor.

\section{P-fertilisation and nutrient availability}

In contrast to sufficient $\mathrm{P}$ and $\mathrm{N}$ foliage contents, the interaction of low $\mathrm{Mg}$ and high $\mathrm{Ca}$ or $\mathrm{K}$ contents among all treatments on both sites has to be regarded critically. In most plants, leaf magnesium content generally ranges around $0.10-0.50 \%$ of dry matter, but $\mathrm{Mg}$ deficits have been reported as common if loamy soils were strongly calcareous while containing low amounts of $\mathrm{Mg}$ or after liming of acidic soils (Bergmann 1993). Furthermore, Mg soil mobility, and thus the uptake by plants, may be diminished if high concentrations of $\mathrm{H}^{+}$, $\mathrm{K}^{+}, \mathrm{Ca}^{2+}, \mathrm{NH}_{4}^{+}$and $\mathrm{Mn}^{2+}$ are available (Mengel and Kirkby 2001). Generally, an excess of macronutrients in soil can create deficiencies of other elements from iron antagonism or cation compensation (Jensen et al. 2010). Furthermore, our data suggests that this became particularly conspicuous if black locust seedlings were treated with PK fertiliser. Due to the fact that all treatments received the same amount of potassium, it can be concluded that potassium in this form is highly accessible for black locust trees. Alongside the ability to reduce $\mathrm{pH}$, potassium can lead to $\mathrm{P}$ availability through cation exchange of $\mathrm{Ca}$ and therefore a phosphate desorption caused by electric negative repulsion (Lammers 1997). Nichols \& Beardsell (1981) and Vanray \& Vandiest (1979) reported an interaction between P and Ca uptake of some species, which in turn could not be confirmed by our results. However, leaf $\mathrm{Ca}$ concentrations over $2 \%$ are much too high and therefore not desirable (Heinsdorf 1987). In contrast to the macronutrient situation, $\mathrm{Mn}$ and Fe leaf contents among most of the treatments of site A were much lower than the published adequate respectively comparative values. Especially high rates of Fe play a key role in the $\mathrm{N}_{2}$ fixing availability of plants (Schubert 2006). Jensen et al. (2010) consider a deficiency of $\mathrm{Mn}$ and $\mathrm{Fe}$ as a possible reason for a high mortality rate among different tree species on a reclaimed mine spoil. Although we have no exact results concerning the soil micronutrient levels of our study sites, it has been reported that even if the micronutrient level in soil is adequate, high soil $\mathrm{pH}$ and carbonate is usually the cause of micronutrient deficiencies in many of the calcareous soils especially in arid regions. In such cases the solubility and availability of micronutrients to plants decrease due to the change of their ionic form to an insoluble hydroxide or oxide of the elements (Brady and 
Weil 2008). Finally, high carbonate content in soils can also lead to a high P immobilisation capacity through the precipitation of Ca phosphates (Freese et al. 1989, Pope \& Andersen 1982, Vetterlein et al. 1999a), even at lower $\mathrm{pH}$ values (Vetterlein et al. 1999b). This might be one of the reasons for the comparatively small increases of extractable soil $\mathrm{P}$ after application. Broadcasting, however, led to an enrichment of phosphorus not only in the top 2-3 $\mathrm{cm}$ (Heinsdorf 1976), but in the whole topsoil $(0-30 \mathrm{~cm})$ that was sampled. Yet, even taking this into account, it is also conceivable that the labile P stocks had been underestimated by the DL-method, as the quality of the potentially available phosphorus is examined but the decisive factors for $\mathrm{P}$ uptake like intensity, rate and buffering of phosphates remain unconsidered. This is usually the cause of weak correlation coefficients of extractable $\mathrm{P}$ in soils and plant yields. However, this effect is quite common for the classic extraction methods like DL, CAL, Olsen $\mathrm{P}$ and the waterbased $\mathrm{P}$ extraction (Scheffer \& Schachtschabel 1998). However, the DL-method is commonly utilised in the Lusatian lignite mining district (Vetterlein et al. 1999b) and is equivalent to the often used Bray Method for P determination on open-cast mine spoils (Vetterlein et al. 1999a). Despite such findings, Jungk et al. (1993) reported that a TSP fertilisation with more than $218 \mathrm{~kg} \mathrm{P}^{-} \mathrm{ha}^{-}$ ${ }^{1}$ was necessary to significantly increase soil available $\mathrm{P}$ in order to achieve full yield in a crop rotation with sugar beet, winter weed, or winter barley, even on fertile, arable soil. Such high dosages of $\mathrm{P}$ fertiliser have been reported as necessary for soils with a high phosphate adsorption capacity (Jamer et al. 1998). Furthermore, negligible increases in soil available $\mathrm{P}$, especially on site A, could also be ascribed to the enhanced uptake of older black locust trees, and a translocation of a considerable proportion to the plant roots. Misra et al. (1998), for example, reported that assimilates are used preferentially by the shoots of Eucalyptus nitens (Deane \& Maiden) if conditions limit photosynthesis, and preferentially by roots if conditions limit nutrient or water uptake. Nevertheless, it remains to be clarified wheather black locust trees distributes nutrients in a similar way. Intensive root development in turn can provide an enhanced $\mathrm{P}$ uptake by plants through a reduction of the diffusion paths in soil (Horst \& Waschkies 1987), as well as through rhizosphere acidification mechanism (Fohse et al. 1991, Gillespie \& Pope 1990 a,b, Horst \& Waschkies 1987). Finally, a positive effect of fertilisation may have been incurred below-ground and therefore unrecognised by our research.

\section{Conclusions}

In the context of the present study, it was demonstrated that a comparatively moderate amount of phosphorus $\left(60 \mathrm{~kg} \mathrm{ha}^{-1}\right)$ had a strong impact on $\mathrm{P}$ uptake and the growth performance of examined black locust seedlings, especially when TSP was applied through banding. Moreover, the nutrition of the studied black locust trees after P fertilisation turned out to be sufficient, despite low soil nutrient contents and the lack of mineral nitrogen fertilisation, suggesting this tree species is suitable for further cultivation on the post-mining landscapes considered in our study. Taken together, these findings may help to improve the current fertilisation practices for recently planted or scheduled SRC black locust plantations even on reclaimed areas with comparable site conditions to increase their woody biomass production or create healthier plants to accelerate a successful reclamation process. Neithertheless, further results from a wider range of years would be required to determine the optimal fertilising intervals, rates and mixtures in order to avoid nutrient deficiency in older black locust trees, while taking P sorption capacity of mine spoils and ion antagonisms into account. For future research we propose the measurement of below-ground biomass in addition to only above- 
ground biomass to fully understand nutrition interactions between above- and below-ground components of black locust trees.

\section{Acknowledgements}

\author{
This research was funded by Vattenfall Europe \\ Mining AG.
}

\section{References}

Abarchi I., Zhang Z.Y., Vanlauwe B., Guo X.P., Wang W.M., Ong'or B.T.I., Timbely D., 2009. Effects of plant age and rock phosphate on quality and nutrient release of legume residue. Pedosphere 19: 78-85. DOI: 10.1016/S1002-0160(08)60086-7.

Aiello A.S., Graves W.R., 1996. Two leguminous tree species differ in growth and ion uptake in Hoagland solution: Phosphorus toxicity in Amur maackia. Journal of Plant Nutrition 19: 1061-1073. DOI: 10.1080/0190416 9609365180.

Antonijevic M.M., Dimitrijevic M.D., Milic S.M., Nujkic M.M., 2012. Metal concentrations in the soils and native plants surrounding the old flotation tailings pond of the Copper Mining and Smelting Complex Bor (Serbia). Journal of Environmental Monitoring 14: 866-877. DOI: $10.1039 / \mathrm{c} 2 \mathrm{em} 10803 \mathrm{~h}$.

Barrington S.F., Cap R., Le Phat Q., 1994. In-storage composting of solid dairy manures. Canadian Agricultural Engineering 36: 225-230.

Bergmann W., 1993. Ernährungsstörungen bei Kulturpflanzen [Nutritional disturbances of cultivated plants]. $3^{\text {rd }}$ Edition. Gustav Fischer Verlag. Jena. Stuttgart. 835 p.

Böhm C., Quinkenstein A., Freese D., 2011. Yield prediction of young black locust (Robinia pseudoacacia L.) plantations for woody biomass production using allometric relations. Annals of Forest Research. 54(2): 215-227.

Böhm C., 2012. Ökonomische und ökologische Bewertung von Agroforstsystemen in der landwirtschaftlichen Praxis [Economic and ecological evaluation of agroforestry systems in farming practice]. Verbundvorhaben AgroForstEnergie. Abschlussbericht Teilvorhaben 2: Rekultivierungsfläche in Brandenburg: 1-125.

Bongarten B.C., Huber D.A., Apsley D.K., 1992. Environmental and genetic influences on short-rotation biomass production of black locust (Robinia pseudoacacia L.) in the Georgia Piedmont. Forest Ecology and Management 55: 315-331. DOI: 10.1016/0378-1127 (92)90108-L.

Boring L.R., Swank W.T. 1984. The role of black locust (Robinia pseudoacacia) in forest succession. Journal of Ecology 72: 749-766. DOI: 10.2307/2259529.
Brady N.C., Weil R.R., 2008. The nature and properties of soils. $14^{\text {th }}$ Edition. Upper Saddle River, N.J.: Pearson Prentice Hall.

Brown K.R., van den Driessche R., 2005. Effects of nitrogen and phosphorus fertilisation on the growth and nutrition of hybrid poplars on Vancouver Island. New Forests 29: 89-104. DOI: 10.1007/s11056-004-5418-4.

Bungart R., Hüttl R.F., 2001. Production of biomass for energy in post-mining landscapes and nutrient dynamics. Biomass and Bioenergy 20: 181-187. DOI: 10.1016/S0961-9534(00) 00078-7.

Crous J.W., Morris A.R., Scholes M.C., 2008. Growth and foliar nutrient response to recent applications of phosphorus $(\mathrm{P})$ and potassium $(\mathrm{K})$ and to residual $\mathrm{P}$ and $\mathrm{K}$ fertiliser applied to the previous rotation of Pinus patula at Usutu, Swaziland. Forest Ecology and Management 256: 712-721. DOI: 10.1016/j.foreco.2008.05.024.

Flinn D.W., James J.M., Hopmans P., 1982. Aspects of phosphorus cycling in radiata pine on a strongly phosphorus-adsorbing soil. Australian Forest Research 12: 19-35.

Fohse D., Claassen N., Jungk A., 1991. Phosphorus efficiency of plants .2. Significance of root radius, root hairs and cation-anion balance for phosphorus influx in 7 plant-species. Plant and Soil 132: 261-272.

Freese D., 1988. Einfluss verschiedener Meliorationsmittel und -verfahren auf den P-Zustand und andere Bodenfruchtbarkeitskennziffern rekultivierter BraunkohlenKippensubstrate [Impact of different melioration means and procedures on the P-nutrition and other soil fertility indexes of reclaimed lignite mine soils], $204 \mathrm{p}$.

Freese D., Pagel H., Katzur J., 1989. Phosphorus status and dynamic in reclaimed mine soils. (P-Zustand und Pdynamik rekultivierter Kippenböden). Wiss. Zeitschrift der Humboldt-Universität zu Berlin. Agrarwiss 38: 3337.

Gillespie A.R., Pope P.E., 1990a. Rhizosphere acidification increases phosphorus recovery of black locust .1. Induced acidification and soil response. Soil Science Society of America Journal 54: 533-537. DOI: 10.2136/ sssaj1990.03615995005400020041x.

Gillespie A.R., Pope P.E., 1990b. Rhizosphere acidification increases phosphorus recovery of black locust 2 . Model predictions and measured recovery. Soil Science Society of America Journal 54: 538-541. DOI: 10.2136/ sssaj1990.03615995005400020042x.

Grünewald H., Böhm C., Quinkenstein A., Grundmann P., Eberts J., von Wühlisch G., 2009. Robinia pseudoacacia L.: A lesser known tree species for biomass production. Bioenergy Research 2: 123-133. DOI: 10.1007/ s12155-009-9038-X.

Heinsdorf D., 1976. Untersuchung über die Wirkung mineralischer Düngung auf das Wachstum und den Ernährungszustand von Kiefernkulturen auf verbreiteten Kippenbodenformen der Niederlausitz [Study on the effect of mineral fertilisation on the growth and nutritional status of pine cultures on common reclaimed mine soil forms of the Lower Lusatia]. Beiträge für die 
Forstwirtschaft 4: 185-197.

Heinsdorf D., 1987. Ergebnisse eines Nährstoffmangelversuchs zur Robinie (Robinia pseudoaccacia L.) auf Kipprohböden [Results of a nutrient-deficient experiment for black locust (Robinia pseudoacacia L.) on unprocessed mine spoils]. Beiträge für die Forstwirtschaft 21: 13-17.

Heinsdorf D., 1992. Untersuchungen zur Düngebedürftigkeit von Forstkulturen auf Kipprohböden der Niederlausitz [Studies on fertiliser demand of forest cultures on unprocessed mine spoils in Lower Lusatia]. Habil., TU-Dresden, Fakultät f. Bau-, Wasser- und Forstwesen, Dresden..

Hoffman G., 1991. Die Untersuchungen von Böden [Soil analysis]. VD-LUFA-Methodenhandbuch Bd. 1. 4. Aufl. VDLUFAVerlag. Darmstadt.

Horst W., Waschkies C., 1987. Phosphatversorgung von Sommerweizen (Triticum aestivum L.) in Mischkultur mit Weißer Lupine (Lupinus albus L.) [Phosphorus nutrition of spring wheat (Triticum aestivum L.) in mixed culture with white lupin (Lupinus albus L.)]. Z. Pflanzenernaehr. Bodenkd. 150: 1-8. DOI: 10.1002/ jpln.19871500102.

Jamer B., Buresh R.J., Place F.M., 1998. Sesbania tree fallows on phosphate-deficent sites: Maize yield and financial benefit. Agronomy Journal 90: 717 - 726. DOI: 10.2134/agronj1998.000219620090 00060001x.

Jensen R.R., Brake S.S., Wolf S.F., Bekker M.F., Hardin P.J., Jackson M.W., 2010. Chemical element concentrations in black locust (Robinia pseudoacacia L.) and green ash (Fraxinus pennsylvanica Marsh.) leaves at the reclaimed Green Valley coal Mine, Indiana, USA. Environmental Earth Sciences 60: 1391-1405. DOI: 10.1007/s12665-009-0275-2.

Jungk A., Claassen N., Schulz V., Wendt J., 1993. Availability of phosphate reserves in arable soils. Zeitschrift für Pflanzenernährung und Bodenkunde 156: 397-406. DOI: $10.1002 /$ jpln. 19931560504.

Katzur J., Hanschke L., 1990. Pflanzenerträge auf meliorierten schwefelhaltigen Kippböden und die bodenkundlichen Zielgrößen der landwirtschaftlichen Rekultivierung [Plant yields on ameliorated sulphurous mine soils and pedological targets of agricultural reclamation]. Arch. Acker-Pflanzenbau Bodenkd 34: 35-43.

Keskin T., Makineci E., 2009. Some soil properties on coal mine spoils reclaimed with black locust (Robinia pseudoacacia L.) and umbrella pine (Pinus pinea L.) in Agacli-Istanbul. Environmental Monitoring and Assessment 159: 407-414. DOI: 10.1007/s10661-008-0638-2.

Lammers A., 1997. Phosphatformen und Phosphatfreisetzung in hochgedüngten Böden Europas [Phosphate forms and release in intensive fertilised soils in Europe]. München: Herbert Utz Verlag.

Landgraf D., Heydeck P., 2014. Pilzinfektionen in neu begründeten Robinienbeständen [Fungal infections of recently planted black locust stands]. AFZ der Wald 2: 44-45.

Marschner H., Marschner P., 2012. Marschner's mineral nutrition of higher plants. London; Waltham, MA: Elsevier/Academic Press.

Mengel K., Kirkby E.A., 2001. Principles of plant nutrition: Kluwer Academic Publishers. DOI: 10.1007/97894-010-1009-2.

Misra R.K., Turnbull C.R.A., Cromer R.N., Gibbons A.K., LaSala A.V., Ballard L.M. 1998. Below-and aboveground growth of Eucalyptus nitens in a young plantation - II. Nitrogen and phosphorus. Forest Ecology and Management 106: 295-306. DOI: 10.1016/S03781127(97)00320-4.

Nichols D.G., Beardsell D.V., 1981. Interactions of calcium, nitrogen and potassium with phosphorus on the symptoms of toxicity in Grevillea $\mathrm{Cv}$ Poorinda Firebird. Plant and Soil 61: 437-445. DOI: 10.1007/ BF02182024.

Ntayombya P., Gordon A.M., 1995. Effects of black locust on productivity and nitrogen nutrition of intercropped Barley. Agroforestry Systems 29: 239-254. DOI: 10.1007/ BF00704871.

Pagel H., Schmieder E., Benkenstein H., 1982. Einfluß langjährig differentierter Düngung auf Kapazitäts-, Qualitäts- und Intensitätswerte des Bodenphosphats im statischen Nähstoffmangelversuchs thyrow [Influence of many years of differentially oriented fertilisation on capacitance, quality and intensity values of the soil phosphate based on a statistical nutrient-deficiency-experiment in Thyrow]. Archiv für Acker- und Pflanzenbau und Bodenkunde 26: 654 -655.

Pope P., Andersen C., 1982. Biomass yields and nutrient removal in short rotation black locust plantations. Proc. Central Hardwood For. Conf.: 244-256.

Reed S.C., Seastedt T.R., Mann C.M., Suding K.N., Townsend A.R., Cherwin K.L., 2007. Phosphorus fertilisation stimulates nitrogen fixation and increases inorganic nitrogen concentrations in a restored prairie. Applied Soil Ecology 36: 238-242. DOI: 10.1016/ j.apsoil.2007.02.002.

Reinsvold R.J., Pope P.E., 1987. Combined effect of soilnitrogen and phosphorus on nodulation and growth of Robinia pseudoacacia. Canadian Journal of Forest Research-Revue Canadienne De Recherche Forestiere 17: 964-969. DOI: 10.1139/x87-150.

Rice S.K., Westerman B., Federici R., 2004. Impacts of the exotic, nitrogen-fixing black locust (Robinia pseudoacacia) on nitrogen-cycling in a pine-oak ecosystem. Plant Ecology 174: 97-107. DOI: 10.1023/B:VEGE.00 00046049.21900.5a.

Römer W., Lehne P., 2004. Neglected P and K fertilisation in organic farming reduces N-2 fixation and grain yield in a red clover-oat rotation. Journal of Plant Nutrition and Soil Science-Zeitschrift fur Pflanzenernahrung und Bodenkunde 167: 106-113. DOI: 10.1002/ jpln.200320337.

Schaaf W., 2001. What can element budgets of false-time series tell us about ecosystem development on post-lignite mining sites? Ecological Engineering 17: 241-252. DOI: 10.1016/S0925-8574(00)00142-7. 
Schachtman D.P., Reid R.J., Ayling S.M., 1998. Phosphorus uptake by plants: From soil to cell. Plant Physiology 116: 447-453. DOI: 10.1104/pp.116.2.447.

Scheffer F., Schachtschabel P., 1998. Lehrbuch der Bodenkunde [Soil science]. 14 ${ }^{\text {th }}$ Edition. Ferdinand Enke Verlag, Stuttgart.

Schramel P., Xu L., Knapp G., Michaelis M., 1993. Multielemetal analysis in biological samples by on-line preconcentration on 8-hydroxyquinoline-cellulose microcolumn coupled to simultaneous ICP-AES. Fresenius' Journal of Analytical Chemistry. 345: 600-606. DOI: 10.1007/BF00325808.

Schubert S., 2006. Pflanzenernährung: Grundwissen Bachelor [Plant nutrition: basics for bachelor students]. Eugen Ulmer KG. Stuttgart.

Smith E.M., 1978. Foliar analysis survey of woody ornamentals. Ohio Agricultural Research and Development Center Research Circular: 30-34.

Vance C.P., 2001. Symbiotic nitrogen fixation and phosphorus acquisition. Plant nutrition in a world of declining renewable resources. Plant Physiology 127: 390397. DOI: $10.1104 / p p .010331$.

Vanray B., Vandiest A., 1979. Utilization of phosphate from different sources by 6 Plant-Species. Plant and
Soil 51: 577-589. DOI: 10.1007/BF02277578.

Vetterlein D., Waschkies C., Weber E., 1999a. Nutrient availability in the initial stages of surface mine spoil reclamation - Impact on plant growth. Journal of Plant Nutrition and Soil Science-Zeitschrift für Pflanzenernährung und Bodenkunde 162: 315-321. DOI: 10.1002/ (SICI)1522-2624(199906)162:3<315::AIDJPLN315>3.0.CO;2-I.

Vetterlein D., Bergmann C., Hüttl R.F., 1999b. Phosphorus availability in different types of open-cast mine spoil and the potential impact of organic matter application. Plant and Soil 213: 189-194. DOI: 10.1023/ A:1004467213912.

Wilden R., Schaaf W., Hüttl R.F., 1999. Soil solution chemistry of two reclamation sites in the Lusatian lignite mining district as influenced by organic matter application. Plant and Soil 213: 231-240. DOI: 10.1023/ A:1004421501867.

Yüksek T., 2012. The restoration effects of black locust (Robinia pseudoacacia L) plantation on surface soil properties and carbon sequestration on lower hillslopes in the semi-humid region of Coruh Drainage Basin in Turkey. Catena 90: 18-25. DOI: 10.1016/j.catena. 2011.10.001. 